University of Nebraska - Lincoln

DigitalCommons@University of Nebraska - Lincoln

Investigations of the Ichthyofauna of

Nicaraguan Lakes

Papers in the Biological Sciences

1976

\title{
The Status of the Freshwater Shark of Lake Nicaragua
}

Thomas B. Thorson

University of Nebraska-Lincoln

Donald E. Watson

University of Lagos

C. Michael Cowan

Associated Environmental Services Corp.

Follow this and additional works at: https://digitalcommons.unl.edu/ichthynicar

Part of the Aquaculture and Fisheries Commons

Thorson, Thomas B.; Watson, Donald E.; and Cowan, C. Michael, "The Status of the Freshwater Shark of Lake Nicaragua" (1976). Investigations of the Ichthyofauna of Nicaraguan Lakes. 37.

https://digitalcommons.unl.edu/ichthynicar/37

This Article is brought to you for free and open access by the Papers in the Biological Sciences at DigitalCommons@University of Nebraska - Lincoln. It has been accepted for inclusion in Investigations of the Ichthyofauna of Nicaraguan Lakes by an authorized administrator of DigitalCommons@University of Nebraska Lincoln. 
Made in United States of America

Reprinted from CopeIA, 1966, No. 3, September 7

pp. 385-402

\section{The Status of the Freshwater Shark of Lake Nicaragua \\ Thomas B. Thorson, Donald E. Watson, and C. Michael Cowan}

Nineteen sharks collected from freshwater at several points on Lake Nicaragua and the Río San Juan were all of the same species and indis tinguishable from marine Carcharhinus leucas of the Atlantic. Minor differences previously thought to separate $C$. leucas from the lake shark proved to be invalid. Females had slightly longer gill slits, somewhat greater breadth of pelvic fin, and a longer abdominal region than males. Clasper length indicated that the onset of sexual maturity in males occurs when they are between 1,600 and $1,700 \mathrm{~mm}$ in total length.

The classical theory or origin of the sharks from Pacific ancestry no longer appears tenable. An Atlantic origin is indicated by (a) strong evidence that the taxonomic affinities not only of the shark, but also of the sawfish and tarpon, are more pronouncedly with Atlantic relatives than with those of the Pacific, (b) recent evidence that Lake Nicaragua may never have been a part of the Pacific but opened originally to the Atlantic, (c) the fact that Lake Nicaragua drains into the Caribbean Sea by a large, broad river, and (d) all three of the large, otherwise marine types of fish occurring in the lake are species that habitually congregate in brackish water and frequently move up rivers.

Evidence that the sharks are not landlocked includes the following facts: (a) they are abundant the full length of the river, (b) barges drawing from one to three feet of water regularly negotiate the river (including all of the rapids) in both directions, (c) sharks were observed both below and above the three major rapids as well as actually in the rapids, most of them headed upstream.

\section{INTRODUCTION}

$\mathrm{T}^{\mathrm{s}}$ HE presence of sharks and sawfish in Lake Nicaragua and its drainage system, the Río San Juan, has been known to the outside world since early in the time of the Spanish Conquest. The first published reference was made by the Spanish historian, Gonzalo Fernández de Oviedo y Valdés (1526, 1535), who mentioned both sharks and sawfish as residents of the lake. He called the latter "guitar fish" (pexe vigüela1), but his description of the "sword" (espada) leaves no doubt that he referred to the sawfish (Pristis).

Epliraim G. Squier (1852), the first United States Minister to Nicaragua, considered Oviedo's statement concerning the sawfish "somewhat apochryphal" although he rec-

1 Vigüela, vihuela, or bigüela is a stringed instrument similar to a guitar. ognized Oviedo as "usually very accurate in matters of this kind." However, Squier stated as a fact that ". . . sharks abound in the lake. They are called 'tigrones' from their rapacity. Instances are known of their having attacked and killed bathers within a stone's throw of the beach at Granada, and I have myself repeatedly seen them from the walls of the old castle, dashing about, with their fins projecting above the water."

Thomas Belt (1874), a mining engineer and naturalist, reported large sharks swimming about the entrance to the Rio San Juan and stated that "large freshwater sharks appear to be common in the lake."

Since the reports of the early chroniclers, the presence of the sharks and sawfish has been given wide publicity in the popular press and news media and has been discussed most thoroughly for both the layman and the zoologist by Archie Carr (1953) in his delightful book, "High Jungles and Low." 
The people of Nicaragua are well aware of the unique distinction of their lake and currently are using a postage stamp whose design includes a shark and a sawfish.

The first scientific treatment of both the shark and sawfish of Lake Nicaragua was that of Gill and Bransford (1877). They gave the first, brief description of the shark and called it Eulamia nicaraguensis. They stated that it was closely allied with $E$. milberti and occurred throughout the length of the Río San Juan. Their description was based on a six-foot, four-inch specimen of undetermined sex, which has been preserved as U. S. National Museum no. 16887.

The appearance of the description of Gill and Bransford prompted Lütken (1879) to publish belatedly a more detailed set of measurements, with a sketch and some notes on coloration of a shark taken by a Prof. $\emptyset$ rstad in 1848. Ørstad regarded it as a new species and titled his sketch Carcharias lacustris. Although Lütken recognized it as the same as Gill and Bransford's E. nicaraguensis, he designated it Carcharias nicaraguensis. No part of this specimen was preserved.

A brief description of the lake shark, no doubt based on the data of Gill and Bransford and of Lütken, was given by Jordan and Evermann (1896a:39) under the name, Carcharhinus nicaraguensis, a combination first used by Jordan (1887) .

The shark is also mentioned in earlier catalogs or checklists of fish, which include Lake Nicaragua, by Eigenmann (1893, 1909), Jordan and Evermann (1896b), Meek (1907), Regan (1908), and Jordan, Evermann and Clark (1930), as well as in brief statements by Gill (1884, 1893) and Smith (1893). The latter three references were in response to a statement by Hardman (1884) and an inquiry by Ames (1893) concerning the occurrence of elasmobranchs in freshwater.

Bigelow and Schroeder (1948), in the most authoritative and comprehensive work on sharks of the region concerned, gave the only reasonably complete treatment, including synonymy, of the Lake Nicaragua shark ever published. They examined what were at that time apparently the only four preserved whole specimens in existence: one male, collected at San Carlos by Major C. $M$. Duke for the Museum of Comparative Zoology at Harvard (Anon., 1943), and three males, also from near San Carlos, collected by Luis Marden (1944). Bigelow and Schroeder at that time regarded the lake shark as C. nicaraguensis, a landlocked offshoot of C. leucas, from which they separated it on the basis of several minor characters. However, the same authors (1961) studied a very small female ( $685 \mathrm{~mm}$ total length) taken by Royal D. Suttkus at Trinidad, about three-fourths of the distance down the Rio San Juan from the lake, plus the jaws of a larger shark from the mouth of the Rio Sapoá, near the village of Sapoá, on Lake Nicaragua. They concluded that the presumed differences were not valid and proposed that $C$. nicaraguensis be placed in the synonymy of $C$. leucas.

Although the freshwater sharks of Lake Nicaragua have generated considerable interest among zoologists as well as laymen, and their occurrence is widely known, the literature concerning them is quite fragmentary and scattered, and very few specimens have actually been studied by qualified people. Recently brief papers have been published concerning physiological aspects of the sharks' biology (Thorson, 1962a, 1962b; Urist, 1962; Oguri, 1964), but there has never been any extensive study of the general biology of the Lake Nicaragua shark. Such a study is now under way, and this paper reports morphometric data which supplement the meager information now available, and discusses some unresolved questions concerning the origin and purported isolation of the shark population in the Lake Nicaragua.

Although our primary emphasis is on the shark, the problems involved are inseparable from those concerning the sawfish, and since both are frequently mentioned together in the literature, we have not attempted to exclude the sawfish from our discussion.

\section{Morphometric Studies}

As discussed below, there has been longstanding differences as to whether the sharks in the lake are actually marine sharks that freely make their way through the river or are landlocked by a series of rapids and therefore represent a distinct, isolated species or subspecies. Although evidence now at hand tends to support the former view, the latter cannot be disregarded in the absence of a definitive answer to the question. The collection site of specimens studied therefore becomes very important. 


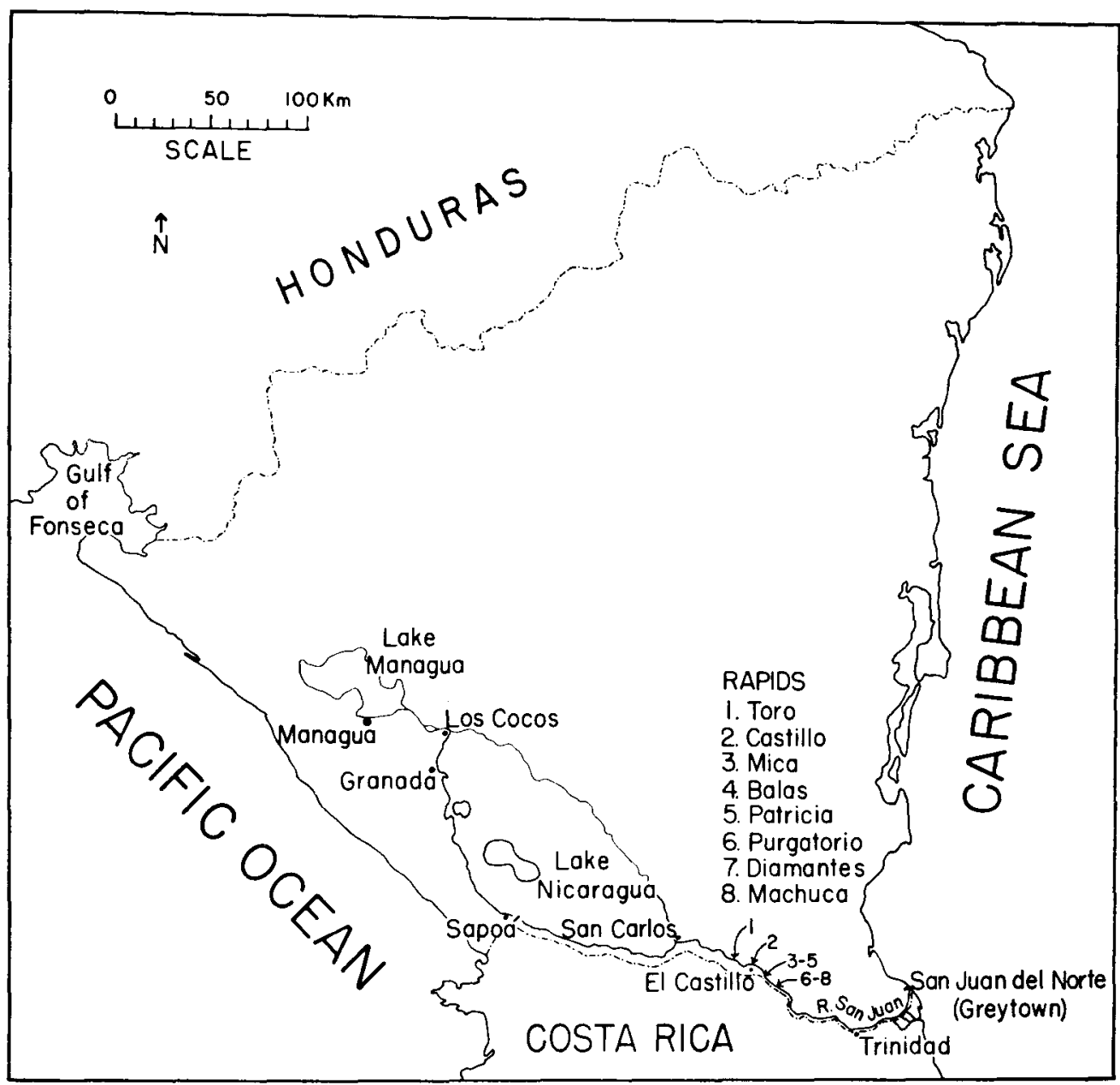

Fig. 1. Map of Nicaragua. (Drawn by Hope D. Watson.)

Of the specimens actually studied to date, that of Gill and Bransford (1877) was taken at an unspecified location. Ørstad's (Lütken, 1879) was from an unrecorded point on the Río San Juan. All four sharks studied by Bigelow and Schroeder in 1948 were from San Carlos, where the Rio San Juan leaves Lake Nicaragua. The single shark studied by Bigelow and Schroeder in 1961 was from the lower reaches of the river, perhaps 30 miles from the mouth and well below the last of the rapids. Those taken at San Carlos could properly be considered a part of the lake population, but those taken in at least the lower third of the river might, if the lake sharks are landlocked, represent marine $C$. leucas wandering up the river, as the species is known to do elsewhere.
It would be of significance then to compare sharks taken at various points in the lake and on the Río San Juan to determine if they are the same, morphologically, throughout the system, particularly above, as compared with below the rapids. Accordingly, we collected numerous sharks and took detailed measurements of the following:

(1) four from Los Cocos, near Granada, at the northwest end of the lake, about 220 miles from the Caribbean Sea (Fig. 1); (2) eight from San Carlos, at the southeast end of the lake, where the river leaves the lake and about 110 miles from the sea; (3) three from El Castillo, at the second rapids (Rápides del Castillo), about 75 miles from the sea; and (4) four from the mouth of the Rio San Juan, at San Juan del Norte (Greytown). 
Table 1. Morphometric Data of Populations of Carcharhinus leucas (IN \% of Total Length). Los Cocos: upper end of Lake Nicaragua, San Carlos: head of the Rio San Juan, El Castillo: 3rd of way down the river, and San Juan del Norte: at mouth of river.

\begin{tabular}{|c|c|c|c|c|c|c|c|c|c|}
\hline \multirow[t]{2}{*}{$\begin{array}{l}\text { Total specimens } \\
\text { Avg length, mm } \\
\text { Range of length, mm }\end{array}$} & \multicolumn{3}{|c|}{$\begin{array}{c}\text { Los Cocos } \\
4 \\
1,662 \\
1,272-1,656\end{array}$} & \multicolumn{3}{|c|}{$\begin{array}{c}\text { San Carlos } 0^{7} \\
3 \\
1,604 \\
1,220-1,852\end{array}$} & \multicolumn{3}{|c|}{$\begin{array}{c}\text { San Carlos } \\
5 \\
1,879 \\
1,710-2,057\end{array}$} \\
\hline & $N$ & $\bar{x}$ & Range & $N$ & $\bar{x}$ & Range & $N$ & $\bar{x}$ & Range \\
\hline \multicolumn{10}{|l|}{ Snout tip to: } \\
\hline Nostrils & 4 & 1.9 & $1.6-2.0$ & 3 & 2.1 & $1.9-2.3$ & 5 & 1.7 & $1.5-2.1$ \\
\hline Eye & 4 & 5.3 & $5.2-5.3$ & 3 & 5.4 & $5.1-5.7$ & 5 & 5.1 & $4.7-5.5$ \\
\hline Mouth & 4 & 6.0 & $5.9-6.1$ & 3 & 6.1 & $5.7-6.3$ & 5 & 5.7 & $5.1-6.4$ \\
\hline 1st gill opening & 4 & 18.4 & $17.5-19.3$ & 3 & 18.8 & $18.2-19.9$ & 5 & 18.1 & $17.5-18.6$ \\
\hline 5 th gill opening & 4 & 22.2 & $20.9-23.7$ & 3 & 22.9 & $21.9-24.7$ & 5 & 22.4 & $21.8-23.2$ \\
\hline Pectoral insertion & 4 & 19.3 & $18.6-20.0$ & 3 & 20.9 & $19.9-22.7$ & 5 & 19.9 & $19.5-20.7$ \\
\hline Pelvic insertion & 4 & 53.3 & $51.7-54.1$ & 3 & 51.7 & $50.1-53.0$ & 5 & 54.1 & $52.1-55.8$ \\
\hline Cloaca & 3 & 54.8 & $54.6-55.0$ & 3 & 54.9 & $53.2-56.2$ & 5 & 57.3 & $55.3-60.0$ \\
\hline Ist dorsal origin & 4 & 29.3 & $27.7-30.4$ & 3 & 29.0 & $28.2-29.8$ & 5 & 29.9 & $28.6-30.6$ \\
\hline 2nd dorsal origin & 4 & 63.9 & $62.7-65.7$ & 3 & 63.9 & $61.8-66.1$ & 5 & 64.9 & $63.1-66.9$ \\
\hline Anal fin origin & 4 & 66.0 & $64.4-68.2$ & 3 & 66.1 & $63.7-67.5$ & 5 & 66.4 & $64.8-68.6$ \\
\hline Upper caudal origin & 4 & 77.4 & $74.8-79.6$ & 3 & 75.9 & $73.8-77.7$ & 5 & 76.5 & $74.3-78.6$ \\
\hline \multicolumn{10}{|l|}{ Distance between bases } \\
\hline 1st and 2nd dorsal & 1 & 21.4 & & 2 & 23.2 & $23.0-23.4$ & 5 & 22.5 & $22.0-23.6$ \\
\hline 2nd dorsal and caudal & & & & 2 & 7.4 & $7.2-7.6$ & 5 & 7.1 & $6.8-7.4$ \\
\hline Pectoral and pelvic & 1 & 24.3 & & 3 & 23.4 & $22.5-24.5$ & 5 & 26.1 & $25.1-27.2$ \\
\hline Pelvic and anal & 1 & 6.0 & & 3 & 8.9 & $8.5-9.7$ & 5 & 6.8 & $6.1-7.1$ \\
\hline Anal and caudal & I & 5.9 & & 3 & 5.6 & $5.1-6.4$ & 5 & 5.2 & $4.8-5.4$ \\
\hline \multicolumn{10}{|l|}{ Pectoral insertion to } \\
\hline pelvic insertion & 4 & 34.3 & $33.8-34.7$ & 3 & 31.1 & $29.8-33.2$ & 5 & 34.4 & $32.9-35.4$ \\
\hline \multicolumn{10}{|l|}{ Nostrils; distance between } \\
\hline \multicolumn{10}{|l|}{ Mouth } \\
\hline Width & 4 & 11.3 & $10.8-11.9$ & 3 & 10.5 & $10.0-10.8$ & 5 & 11.0 & $10.2-11.7$ \\
\hline Length & 4 & 4.3 & $3.9-4.6$ & 3 & 4.7 & $4.5-4.9$ & 5 & 4.9 & $4.7-5.3$ \\
\hline \multicolumn{10}{|l|}{ Gill opening lengths } \\
\hline lst & 4 & 3.4 & $3.3-3.6$ & 3 & 3.1 & $2.7-3.5$ & 5 & 3.7 & $3.3-3.9$ \\
\hline 2nd & 4 & 3.9 & $3.7-4.0$ & 3 & 3.5 & $3.2-3.9$ & 5 & 4.1 & $3.5-4.5$ \\
\hline 3rd & 4 & 4.0 & $3.9-4.2$ & 3 & 3.6 & $3.2-3.9$ & 5 & 4.2 & $3.7-4.5$ \\
\hline 4 th & 4 & 3.5 & $3.1-3.7$ & 3 & 3.3 & $2.9-3.6$ & 5 & 3.6 & $3.4-3.9$ \\
\hline 5 th & 4 & 2.8 & $2.4-3.0$ & 3 & 2.7 & $2.3-3.1$ & 5 & 2.8 & $2.6-3.0$ \\
\hline Horizontal eye diam & 4 & 0.83 & $0.7-0.9$ & 2 & 0.8 & $0.7-0.9$ & 5 & 0.7 & $0.6-1.0$ \\
\hline \multicolumn{10}{|l|}{ Ist dorsal fin } \\
\hline Length base & 4 & 12.6 & $12.0-13.6$ & 3 & 12.1 & $11.6-13.0$ & 5 & 12.5 & $11.9-13.1$ \\
\hline Length post. margin & 4 & 4.2 & $4.0-4.4$ & 3 & 4.0 & $3.6-4.3$ & 5 & 4.0 & $3.4-4.5$ \\
\hline Height & 4 & 13.0 & $12.3-13.5$ & 3 & 12.4 & $12.0-12.6$ & 5 & 12.2 & $11.7-13.3$ \\
\hline \multicolumn{10}{|l|}{ 2nd dorsal fin } \\
\hline Length base & 4 & 5.1 & $4.8-5.6$ & 3 & 5.0 & $4.9-5.1$ & 5 & 4.9 & $4.7-5.1$ \\
\hline Length post. margin & 4 & 4.0 & $3.7-4.3$ & 3 & 3.7 & $3.3-4.0$ & 5 & 3.7 & $3.1-4.1$ \\
\hline Height & 3 & 4.8 & $4.5-5.1$ & 3 & 4.3 & $4.0-4.6$ & 5 & 4.3 & $4.2-4.6$ \\
\hline \multicolumn{10}{|l|}{ Anal fin } \\
\hline Length base & 4 & 4.7 & $4.2-5.0$ & 3 & 4.4 & $4.0-4.9$ & 5 & 4.6 & $4.3-5.0$ \\
\hline Length post. margin & 4 & 3.5 & $3.4-3.8$ & 3 & 3.3 & $3.0-3.6$ & 5 & 3.2 & $3.0-3.5$ \\
\hline Height & 4 & 5.1 & $4.7-5.4$ & $\mathbf{3}$ & 4.6 & $4.2-5.2$ & 5 & 4.8 & $4.5-5.2$ \\
\hline \multicolumn{10}{|l|}{ Pectoral fin; length } \\
\hline Anterior margin & 4 & 22.0 & $21.3-23.0$ & 3 & 20.6 & $20.2-21.1$ & 5 & 21.1 & $20.4-21.8$ \\
\hline Distal margin & 4 & 21.3 & $19.6-22.2$ & 3 & 19.2 & $18.4-20.3$ & 5 & 19.8 & $19.2-20.6$ \\
\hline Post. margin & 3 & 5.9 & $5.8-6.1$ & 3 & 5.6 & $5.1-5.9$ & 5 & 5.7 & $5.1-6.7$ \\
\hline \multicolumn{10}{|l|}{ Pelvic fin; length } \\
\hline Anterior margin & 4 & 7.8 & $7.4-8.3$ & 3 & 7.4 & $6.7-8.0$ & 5 & 7.5 & $7.2-8.0$ \\
\hline Distal margin & 4 & 8.4 & $7.9-9.0$ & 3 & 7.2 & $6.5-8.0$ & 5 & 8.1 & $7.7-8.6$ \\
\hline Caudal fin; length & & & & & & & & & \\
\hline Dorsal lobe & 4 & 27.9 & $27.1-29.4$ & 3 & 28.2 & $26.8-30.3$ & 5 & 27.5 & $26.7-27.9$ \\
\hline Ventral lobe & 4 & 13.2 & $12.9-13.9$ & 3 & 12.8 & $12.4-13.6$ & 3 & 12.7 & $12.5-13.1$ \\
\hline Precaudal vertebrae & & No & Data & & No & Data & 2 & 111 & $110-112$ \\
\hline Caudal vertebrae & & No 1 & Data & & No & Data & 2 & 95.5 & $93-98$ \\
\hline Dental formula & & $\frac{12-1-1}{12-}$ & $\frac{12 \text { or } 13}{1-12}$ & & $\frac{\mathrm{r} 13-0 \mathrm{c}}{12-}$ & or $1-12$ or 13 & $\frac{12 \text { or }}{12}$ & $\frac{\mathrm{r} 13-0 \mathrm{o}}{\mathrm{or} 13-1}$ & or $1-12$ or 15 \\
\hline
\end{tabular}


TABLE 1. (Continued.)

\begin{tabular}{|c|c|c|c|c|c|c|c|c|c|}
\hline \multirow[t]{2}{*}{$\begin{array}{l}\text { Total specimens } \\
\text { Avg length, mm } \\
\text { Range of length, mm }\end{array}$} & \multicolumn{3}{|c|}{$\begin{array}{c}\text { El Castillo } \\
3 \\
1,658 \\
1,584-1,700\end{array}$} & \multicolumn{3}{|c|}{$\begin{array}{c}\text { San Juan del Norte } \\
4 \\
\mathbf{4} \\
1,475-1,740\end{array}$} & \multicolumn{3}{|c|}{$\begin{array}{c}\text { Summary, all locations } \\
19 \\
1,689 \\
1,220-2,057\end{array}$} \\
\hline & $N$ & $\overline{\vec{x}}$ & Range & $N$ & $\bar{x}$ & Range & $N$ & $\bar{x}$ & Range \\
\hline \multicolumn{10}{|l|}{ Snout tip to: } \\
\hline Nostrils & 3 & 1.6 & $1.4-2.0$ & 4 & 1.4 & $1.2-1.7$ & 19 & 1.7 & $1.2-2.3$ \\
\hline Eye & 3 & 5.2 & $4.9-5.5$ & 4 & 4.9 & $4.5-5.2$ & 19 & 5.2 & $4.5-5.7$ \\
\hline Mouth & 3 & 5.9 & $5.7-6.2$ & 4 & 5.4 & $5.0-5.5$ & 19 & 5.8 & $5.0-6.4$ \\
\hline 1st gill opening & 3 & 19.1 & $18.9-19.5$ & 4 & 17.8 & $17.4-18.5$ & 19 & 18.4 & $17.4-19.9$ \\
\hline 5 th gill opening & 3 & 23.8 & $23.5-24.1$ & 4 & 22.2 & $21.2-22.7$ & 19 & 22.6 & $20.9-24.7$ \\
\hline Pectoral insertion & 3 & 20.7 & $20.0-21.2$ & 4 & 19.3 & $18.3-20.4$ & 19 & 20.0 & $18.3-22.7$ \\
\hline Pelvic insertion & 3 & 51.0 & $49.7-51.9$ & 4 & 52.0 & $51.5-52.9$ & 19 & 52.6 & $49.7-55.8$ \\
\hline Cloaca & 3 & 54.6 & $53.5-55.3$ & 4 & 54.9 & $54.2-55.9$ & 18 & 55.5 & $53.2-60.0$ \\
\hline lst dorsal origin & 3 & 29.5 & $29.2-29.9$ & 4 & 29.1 & $28.0-30.3$ & 19 & 29.4 & $27.7-30.6$ \\
\hline 2nd dorsal origin & 3 & 62.1 & $61.5-62.8$ & 4 & 62.3 & $61.6-63.5$ & 19 & 63.5 & $61.5-66.9$ \\
\hline Anal fin origin & 3 & 64.4 & $64.3-64.6$ & 4 & 64.4 & $63.8-65.2$ & 19 & 65.5 & $63.7-68.6$ \\
\hline Upper caudal origin & 3 & 74.6 & $74.0-75.5$ & 4 & 74.7 & $74.4-75.2$ & 19 & 75.9 & $73.8-79.6$ \\
\hline \multicolumn{10}{|l|}{ Distance between bases } \\
\hline 1st and 2nd dorsal & 3 & 20.6 & $20.3-20.9$ & 4 & 21.7 & $21.0-22.5$ & 15 & 21.9 & $20.3-23.6$ \\
\hline 2nd dorsal and caudal & 3 & 7.6 & $7.2-8.0$ & 4 & 7.7 & $7.1-8.1$ & 14 & 7.4 & $6.8-8.1$ \\
\hline Pectoral and pelvic & 3 & 22.5 & $20.9-24.4$ & 4 & 25.4 & $25.2-25.6$ & 16 & 24.6 & $20.9-27.2$ \\
\hline Pelvic and anal & 3 & 7.5 & $6.8-8.6$ & 4 & 6.6 & $6.4-6.8$ & 16 & 7.2 & $6.0-9.7$ \\
\hline Anal and caudal & 3 & 5.5 & $5.1-6.0$ & 4 & 5.6 & $5.1-6.1$ & 16 & 5.5 & $4.8-6.4$ \\
\hline \multicolumn{10}{|l|}{ Pectoral insertion to } \\
\hline pelvic insertion & 3 & 30.5 & $28.9-32.0$ & 4 & 33.1 & $32.7-33.6$ & 19 & 32.9 & $28.9-35.4$ \\
\hline \multicolumn{10}{|l|}{ Nostrils; distance between } \\
\hline inner corners & 3 & 6.5 & $6.4-6.7$ & 4 & 6.5 & $6.3-6.7$ & 19 & 6.7 & $6.2-8.3$ \\
\hline \multicolumn{10}{|l|}{ Mouth } \\
\hline Width & 3 & 10.9 & $10.5-11.5$ & 4 & 10.6 & $10.0-11.0$ & 19 & 10.9 & $10.0-11.9$ \\
\hline Length & 3 & 5.3 & $5.2-5.4$ & 4 & 4.9 & $4.6-5.3$ & 19 & 4.8 & $3.9-5.4$ \\
\hline \multicolumn{10}{|l|}{ Gill opening lengths } \\
\hline lst & 3 & 3.3 & $3.0-3.5$ & 4 & 3.7 & $3.2-4.3$ & 19 & 3.5 & $2.7-4.3$ \\
\hline 2nd & 3 & 3.7 & $3.2-4.1$ & 4 & 4.2 & $3.6-4.9$ & 19 & 3.9 & $3.2-4.9$ \\
\hline 3rd & 3 & 3.7 & $3.2-4.2$ & 4 & 4.3 & $3.6-5.1$ & 19 & 4.0 & $3.2-5.1$ \\
\hline 4th & 3 & 3.4 & $3.2-3.8$ & 4 & 3.9 & $3.3-4.7$ & 19 & 3.6 & $2.9-4.7$ \\
\hline 5th & 3 & 2.6 & $2.5-2.9$ & 4 & 3.0 & $2.5-3.6$ & 19 & 2.8 & $2.3-3.6$ \\
\hline Horizontal eye diam & 3 & 0.8 & $0.8-0.8$ & 4 & 0.8 & $0.7-0.9$ & 18 & 0.79 & $0.6-1.0$ \\
\hline \multicolumn{10}{|l|}{ Ist dorsal fin } \\
\hline Length base & 3 & 12.0 & $11.7-12.4$ & 4 & 11.8 & $11.6-12.1$ & 19 & 12.2 & $11.6-13.6$ \\
\hline Length post. margin & 3 & 4.2 & $3.8-4.5$ & 4 & 4.3 & $4.1-4.6$ & 19 & 4.1 & $3.4-4.6$ \\
\hline Height & 3 & 12.7 & $12.7-12.9$ & 4 & 12.1 & $11.3-12.8$ & 19 & 12.5 & $11.3-13.5$ \\
\hline \multicolumn{10}{|l|}{ 2nd dorsal fin } \\
\hline Length base & 3 & 5.0 & $4.8-5.4$ & 4 & 5.0 & $4.5-5.2$ & 19 & 5.0 & $4.5-5.6$ \\
\hline Length post. margin & 3 & 3.8 & $3.8-3.9$ & 4 & 3.8 & $3.5-4.1$ & 19 & 3.8 & $3.1-4.3$ \\
\hline Height & 3 & 4.6 & $4.4-4.8$ & 4 & 4.4 & $4.3-4.6$ & 18 & 4.5 & $4.0-5.1$ \\
\hline \multicolumn{10}{|l|}{ Anal fin } \\
\hline Length base & 3 & 4.4 & $4.4-4.5$ & 3 & 4.7 & $4.2-5.0$ & 18 & 4.6 & $4.0-5.0$ \\
\hline Length post. margin & 3 & 3.4 & $3.1-3.6$ & 3 & 3.4 & $3.3-3.5$ & 18 & 3.4 & $3.0-3.8$ \\
\hline Height & 3 & 5.0 & $4.7-5.3$ & 3 & 4.9 & $4.6-5.1$ & 18 & 4.9 & $4.2-5.4$ \\
\hline \multicolumn{10}{|l|}{ Pectoral fin; length } \\
\hline Anterior margin & 3 & 22.1 & $21.4-22.5$ & 4 & 21.7 & $21.5-21.8$ & 19 & 21.5 & $20.2-23.0$ \\
\hline Distal margin & 3 & 20.7 & $20.2-21.2$ & 4 & 20.4 & $19.6-21.1$ & 19 & 20.3 & $18.4-22.2$ \\
\hline Post. margin & 3 & 5.9 & $5.4-6.4$ & 4 & 6.0 & $5.6-6.4$ & 18 & 5.8 & $5.1-6.7$ \\
\hline Pelvic fin; length & & & & & & & & & \\
\hline Anterior margin & 3 & 7.9 & $7.7-8.2$ & 4 & 7.6 & $7.3-8.1$ & 19 & 7.6 & $6.7-8.3$ \\
\hline Distal margin & 3 & 8.0 & $7.6-8.3$ & 4 & 8.0 & $7.7-8.4$ & 19 & 8.0 & $6.5-9.0$ \\
\hline Caudal fin; length & & & & & & & & & \\
\hline Dorsal lobe & 2 & 28.5 & $28.1-28.8$ & 4 & 28.4 & $28.2-28.8$ & 18 & 28.0 & $26.7-30.3$ \\
\hline Ventral lobe & & & & 4 & 12.9 & $12.5-13.3$ & 14 & 12.9 & $12.4-13.9$ \\
\hline Precaudal vertebrae & & No & Data & 1 & 111 & & 3 & 111 & $110-112$ \\
\hline Caudal vertebrae & & No & Data & 1 & 96 & & 3 & 95.6 & $93-98$ \\
\hline Dental formula & & $13-$ & $1-13$ & 12 or & $13-0$ & $1-12$ or 13 & 12 or & $\mathrm{r} 13-0 \mathrm{o}$ & or $1-12$ or 15 \\
\hline & & $12-$ & $\overline{1-12}$ & & & & & r 1 & -12 or 13 \\
\hline
\end{tabular}


All were collected in June 1963, except the Los Cocos sharks, taken in July 1963, and four of the eight San Carlos sharks, taken in August 1964. Measurements were essentially those used by the U. S. National Museum. Specimens were caught on various sized shark hooks, baited with several kinds of fish. All measurements were made on freshly caught animals. Some measurements are shown in Table 1. A copy of all measurements is in the possession of $\mathrm{J}$. A. F. Garrick, who is preparing a revision of the genus Carcharhinus.

Table I discloses considerable variability in most of the measurements. This may be partially due to differences in judgment from one time to another, as well as from one individual to another, since all three of us took measurements at various times. Certainly, however, fairly wide variability normally occurs, because frequently the variations within a group are as great as those between groups. Furthermore, similar variability is shown in other data including the measurements of marine $C$. leucas of Clark and von Schmidt (1965), those of the two freshwater specimens cited by Bigelow and Schroeder (1948), and those of Schwartz (1959, 1960).

The slightly greater height of the first and second dorsal fins of our specimens as compared with some others undoubtedly resulted from our taking these measurements from the surface of the back rather than from the axil of the fin.

Present compared with previous data on Lake Nicaragua sharks.-Our figures have been compared with all published measurements on the Lake Nicaragua shark known to us.

Gill and Bransford's description (1877) is incomplete, and does not have explicit measurements or percentages of total or standard length. Statements on the shape of snout, nature of the teeth, and dental formula are in general agreement with our observations. But the proportions given between certain measurements and others agree only loosely or sometimes scarcely at all. The reason is probably to be found in the circumstances of the collection and preservation of the specimen. Dr. J. F. Bransford, a naval physician, collected the shark and presumably measured the total length $\left(6^{\prime} 4^{\prime \prime}\right)$ and preserved the skin, skull, and jaws. It is neither known how it was preserved nor who took the other measurements. However, it appears likely that Gill took the measurements from the skin after preservation and shipment to the U. S. National Museum.

The specimen of Ørstad (Lütken, 1879) was measured in some detail by $\emptyset$ rstad when it was freshly caught, but he did not record its total length. His measurements are listed in three columns, labeled prime, double prime, and triple prime. Lütken must have assumed these to represent feet, inches, and fractions of inches, since he estimated the length as five and one-half feet. However, the shark reconstructed on this basis is hopelessly out of proportion for any known shark species, and Lütken himself remarked that "Some of this information is undeniably a little obscure." We believe that the units are decimeters, centimeters, and millimeters. Using metric units, the reconstructed animal

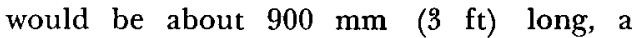
reasonably well-proportioned lake shark probably weighing about $15 \mathrm{lb}$. Thus interpreted, the measurements agree with ours in general, although not perfectly. It is impossible to draw any firm conclusions, although there is no good reason to believe that he was not dealing with the same species as we are.

Bigelow and Schroeder (1948) gave the measurements of two fairly small males $(1,511$ and $1,568 \mathrm{~mm}$ total length). In Table 2 these can be compared with our ranges for 19 specimens. In most parameters, Bigelow and Schroeder's specimens either lie within our ranges or one may be slightly above or below our extremes. There are several measurements, however, in which their figures are beyond our ranges. These include the distances from the snout to the second dorsal fin, upper caudal fin, pelvic fin, and anal fin; distance between origins of pectoral and pelvic fins; and the length of the bases of the second dorsal fin and anal fin. Concerning the latter two, the soft membrane that joins the posterior part of the base of each fin with the body wall is stretched tight if the fin is lifted away from the body and collapses when the fin is released. It seems probable that the differences in measurements represent a difference in the treatment of this membrane in taking the measurement, or possibly in the condition of the specimens when measured, since those of Bigelow and Schroeder were preserved and ours were fresh. In any case, it does not appear to represent anything significant. The 
other differences involve that portion of the trunk which in general lies between the pelvic and pectoral fins. All the measurements of Bigelow and Schroeder's specimens are beyond the small end of our ranges and indicate that the body is shorter in that region. This can hardly be ascribed to preservation, but, as brought out below, is probably related to sex. Both of the specimens involved were immature males.

Comparison of geographic series.-On examining the data from collections made at the four locations (Table 1), we have been unable to detect any single feature or combination of features which exhibits any real pattern of difference between geographic groups. At first glance there may appear to be differences, but when studied closely, they prove to be more apparent than real. For example, the prenarial length (snout tip to nostrils) of Los Cocos sharks $(1.9 \%)$ is greater than that of the San Juan del Norte group $(1.4 \%)$, but the ranges of these overlap, and the Los Cocos range is completely within that of San Carlos as well as of El Castillo. Four individuals are not enough to establish a statistically valid difference.

We can only conclude that there is no substantial difference between sharks taken at different locations and that, on the basis of work done so far, only one species is represented in all parts of the lake and the Río San Juan.

Comparison of Lake Nicaragua sharks with marine C. leucas.-Material for comparison of the Lake Nicaragua shark with marine $C$. leucas has until recently been quite limited. It is now possible to compare data from our 19 freshwater specimens (Table 2) with those published by Clark and von Schmidt (1965) on 33 marine bull sharks from Florida waters and four very large specimens measured by Schwartz (1959, 1960) from Chesapeake Bay, as well as one cited by Bigelow and Schroeder (1948). The complete patterns of our specimens and those of Clark and von Schmidt are remarkably similar. There appears to be, if anything, closer agreement than with the figures for Bigelow and Schroeder's freshwater specimens. Our figures also are in quite close agreement with those of Schwartz, although there are somewhat greater variations between our series and his. These differences are almost certainly related to the size of his specimens, three of which are the largest measured oncs on record. The variability in both the freshwater and marine series is great enough to render small apparent differences in individual measurements insignificant, and there is no discernible pattern of differences.

Comparison of Lake Nicaragua sharks with freshwater sharks of Lake Jamoer, New Guinea.-In 1956, Boeseman reported the occurrence of freshwater sharks in Lake Jamoer, and sawfish in Lake Sentani, both in New Guinea. In 1964 he published a detailed de. scription of the sharks, based on one small female and two larger male specimens. He identified them as $C$. leucas. The ranges of most of his measurements are included in Table 2. These measurements agree very closely with the others in that table, and there appears to be no doubt that the Lake Jamoer population has properly been assigned to C. leucas.

Nullification of supposed differences between $\mathrm{C}$. leucas and C. nicaraguensis.-Before Bigelow and Schroeder proposed synonymizing C. nicaraguensis with C. leucas (1961), they stated the following as characters distin. guishing the former from the latter (1948): “(1) anterior margin of eye posterior to front of mouth by a distance equal to half its own diameter in nicaraguensis (a little anterior to front of mouth in leucas); (2) gill openings relatively somewhat longer in nicaraguensis, the third being nearly $2 / 3$ as long as the distance between nostrils (in leucas the third is a little less than half that long); (3) free tip of second dorsal about $2 / 3$ as long as its base in nicaraguensis (only about half that long in leucas)."

We found, in the freshwater sharks, the position of the eye, was actually anterior to the mouth by an average of more than $2 / 3$ of the diameter of the eye. The individual figures showed the eye anterior to the mouth without a single exception.

In regard to the length of the gill openings, the stated differences do not appear to be valid. The single marine $C$. leucas cited by Bigelow and Schroeder (1948) had gill openings all at the short end of, but not beyond, the range of our freshwater specimens. However, our single specimen with the longest gill slits, representing the highest figures for each of the five gill openings shown in Tables 1 and 2, was a female taken in the Río San Juan at San Juan del Norte, within 300 yards of the Caribbean Sea. The one with the shortest gill openings was a 
Table 2. Comparison of Morphometric Data of Carcharhinus leucas with Previous Records (in \% of Total Length).

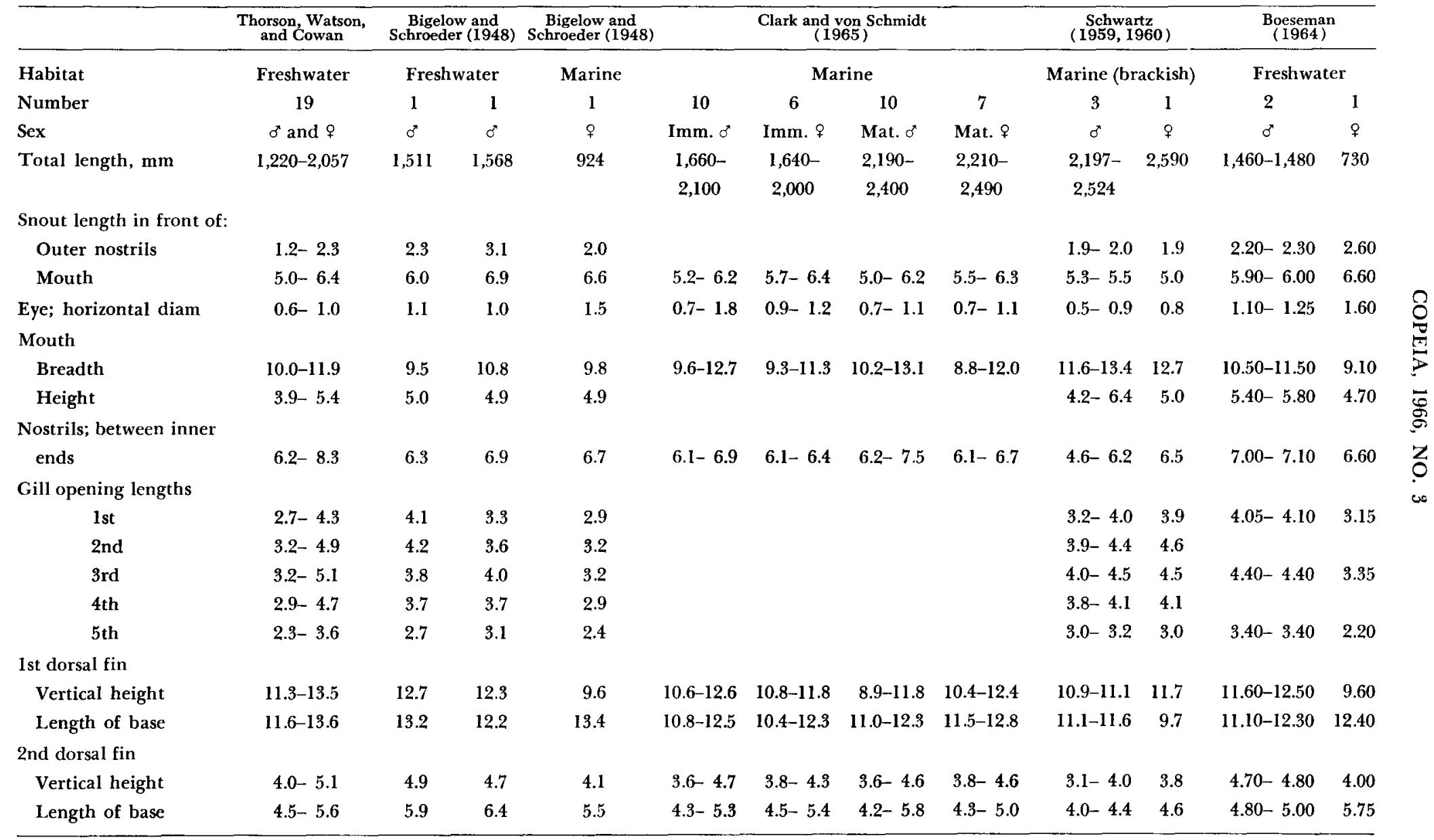


TABle 2. (Continued.)

\begin{tabular}{|c|c|c|c|c|c|c|c|c|c|c|c|c|}
\hline Anal fin & $\begin{array}{c}\text { Thorson, Watson, } \\
\text { and Cowan }\end{array}$ & \multicolumn{2}{|c|}{$\begin{array}{c}\text { Bigelow and } \\
\text { Schroeder (1948) }\end{array}$} & \multicolumn{2}{|l|}{$\begin{array}{c}\text { Bigelow and } \\
\text { Schroeder (1948) }\end{array}$} & \multicolumn{3}{|c|}{$\begin{array}{c}\text { Clark and von Schmidt } \\
(1965)\end{array}$} & \multicolumn{2}{|c|}{$\begin{array}{c}\text { Schwartz } \\
(1959,1960)\end{array}$} & \multicolumn{2}{|c|}{$\begin{array}{c}\text { Boeseman } \\
(1964)\end{array}$} \\
\hline & & & & & & & & & & & & \\
\hline Vertical height & $4.2-5.4$ & 5.3 & 5.4 & 4.9 & $3.6-5.3$ & $3.6-5.1$ & $3.8-4.8$ & $4.0-4.9$ & $4.1-4.7$ & 4.9 & $5.00-5.50$ & 4.40 \\
\hline Length of base & $4.0-5.0$ & 6.0 & 5.3 & 5.3 & $4.1-4.9$ & $4.3-4.9$ & $3.5-4.9$ & $4.2-5.0$ & $4.1-5.0$ & 4.1 & $4.70-4.90$ & 5.20 \\
\hline \multicolumn{13}{|l|}{ Caudal fin; margin } \\
\hline Upper & $26.7-30.3$ & 27.1 & 29.6 & 28.3 & $27.1-30.3$ & $26.6-27.5$ & $24.0-27.8$ & $25.5-28.0$ & $25.4-26.8$ & 26.3 & $28.00-28.00$ & 27.50 \\
\hline Lower & $12.4-13.9$ & 13.2 & 13.6 & 12.3 & $11.9-14.9$ & $12.0-13.2$ & $10.7-13.7$ & $11.9-13.9$ & $12.1-12.7$ & 12.9 & $13.80-14.00$ & 12.60 \\
\hline \multicolumn{13}{|l|}{ Pectoral fin; margin } \\
\hline Outer & $20.2-23.0$ & 21.9 & 23.6 & 20.6 & $20.0-23.6$ & $20.6-21.9$ & $18.8-22.2$ & $21.0-22.6$ & $19.2-20.1$ & 21.7 & $23.00-23.50$ & 19.20 \\
\hline Inner & $5.1-6.7$ & 6.4 & 6.5 & 6.6 & $5.1-6.3$ & $5.1-7.0$ & $5.1-6.3$ & $4.8-6.3$ & $4.6-5.6$ & 5.5 & $5.80-6.80$ & 5.30 \\
\hline Distal & $18.4-22.2$ & 19.6 & 20.4 & 17.6 & $17.5-21.4$ & $18.2-20.2$ & $16.3-19.5$ & $17.9-21.4$ & $17.5-19.3$ & 21.0 & $21.00-22.50$ & 15.00 \\
\hline \multicolumn{13}{|l|}{ Distance from snout to } \\
\hline lst dorsal & $27.7-30.6$ & 27.6 & 27.9 & 27.0 & $26.8-32.9$ & $27.8-29.8$ & $27.4-30.6$ & $28.6-32.0$ & $29.3-30.2$ & 31.4 & $28.50-28.50$ & 28.00 \\
\hline 2nd dorsal & $61.5-66.9$ & 61.0 & 56.6 & 60.0 & $59.0-65.4$ & $61.0-63.0$ & $61.5-64.4$ & $61.7-67.3$ & $58.4-63.6$ & 67.2 & $60.00-62.50$ & 61.00 \\
\hline Upper caudal & $73.8-79.6$ & 72.9 & 70.4 & 71.7 & $72.1-75.5$ & $72.5-74.5$ & $71.5-78.7$ & $72.0-78.0$ & $70.9-76.4$ & 77.2 & $72.00-73.00$ & 74.00 \\
\hline Pectoral & $18.3-22.7$ & 22.3 & 20.4 & 21.4 & $18.2-23.8$ & $19.7-21.9$ & $19.2-23.6$ & $19.5-23.6$ & $17.2-21.9$ & 21.8 & $20.00-20.50$ & 20.50 \\
\hline Pelvic & $49.7-55.8$ & 47.7 & 44.9 & 48.3 & $48.6-50.5$ & $49.9-53.9$ & $48.3-58.0$ & $52.0-58.0$ & $51.2-53.1$ & 55.6 & $49.00-49.00$ & 48.00 \\
\hline Anal & $63.7-68.6$ & 61.4 & 58.1 & 60.0 & $63.7-68.4$ & $62.7-67.1$ & $61.8-72.4$ & $66.5-70.0$ & $64.6-67.2$ & 67.0 & $62.00-63.50$ & 61.50 \\
\hline \multicolumn{13}{|l|}{ Interspace between: } \\
\hline 1st and 2nd dorsals & $20.3-23.6$ & 21.8 & 19.9 & 21.0 & $20.2-23.2$ & $18.2-23.1$ & $20.8-23.2$ & $21.0-24.4$ & $22.7-23.1$ & 22.0 & $20.00-22.00$ & 21.00 \\
\hline 2nd dorsal and caudal & $6.8-8.1$ & 7.0 & 7.9 & 7.0 & $6.7-8.4$ & $4.0-7.7$ & $6.5-8.6$ & $6.5-7.5$ & $7.8-9.3$ & 8.1 & $6.85-7.75$ & 7.10 \\
\hline Anal and caudal & $4.8-6.4$ & 5.8 & 5.9 & 5.5 & $4.8-6.2$ & $2.4-6.0$ & $4.5-8.0$ & $5.5-5.9$ & $5.5-6.4$ & 5.6 & $5.40-5.50$ & 5.75 \\
\hline \multicolumn{13}{|l|}{$\begin{array}{l}\text { Distance from origin to } \\
\text { origin of pectoral and }\end{array}$} \\
\hline pelvics & $28.9-35.4$ & 28.6 & 28.0 & 28.4 & & & & & $24.8-27.0$ & 26.9 & $29.00-29.50$ & 27.50 \\
\hline
\end{tabular}


male taken at San Carlos within 100 yards of the lake. Its measurements, which represent the lowest figures for each of the five gill openings shown in Tables 1 and 2, were almost identical with those of Bigelow and Schroeder's immature female marine specimen. The figures given by Schwartz all lie, within our ranges. The lengths of the third gill opening averaged (in 19 freshwater specimens) approximately 0.6 of the distance between nostrils. The figure for the single marine specimen of Bigelow and Schroeder is 0.47 but we have an individual freshwater specimen with a figure of 0.49 . The figure for the four marine (or brackish water) specimens of Schwartz is 0.73 .

Thirdly, regarding the free tip of the second dorsal fin, we have no figures for marine $C$. leucas, but the average figure of our 19 specimens showed that the free tip of the second dorsal fin is 0.76 as long as its base. If we consider our San Juan del Norte series, taken at the mouth of the Río San Juan, as marine $C$. leucas and compare it with the other three series, progressively farther from the sea, we find the San Juan del Norte series with a figure of $0.76, \mathrm{E} 1$ Castillo 0.76, San Carlos 0.75, and Los Cocos 0.78 . These differences are too small to be meaningful and we conclude that the stated difference is invalid.

We are in full agreement with Bigelow and Schroeder (1961) when they nullified the characters supposedly separating $C$. leucas from $C$. nicaraguensis, and we are also fully convinced that they were correct in placing $C$. nicaraguensis in the synonymy of $C$. leucas.

Dental formula.-All the specimens we have examined had consistently 12 or 13 tooth rows on each side of both the upper and lower jaws, and either one or no symphyseal tooth rows in the upper jaw and always one in the lower. This is consistent with the figures of Gill and Bransford (1877) $\left(\frac{12-1-12}{12-1-12}\right)$ and of Bigelow and Schroeder (1948) $\left(\frac{12 \text { or } 13-0 \text { or } 1-12 \text { or } 13}{12-1-12}\right)$ for freshwater sharks. It is also compatible with Bigelow and Schroeder's dental formula for marine $C$. leucas $\left(\frac{12 \text { or } 13-1-12 \text { or } 13}{12 \text { or } 13-1-12 \text { or } 13}\right)$, and with Springer's data (1960, pers. comm.), with the exception of one of his specimens which had 14 rows on each side of the upper jaw. The dental formulae given by Schwartz $(1959,1960)$ for four $C$. leucas taken in
Chesapeake Bay also agree, except one apparently anomalous male which had only 10 tooth rows in the right side of the lower jaw.

Vertebral counts. -We made precaudal vertebral counts of three sharks, all females, two from San Carlos and one from San Juan del Norte. The counts were 110,112 , and 111 respectively, averaging 111 . J. A. F. Garrick determined the caudal vertebral numbers of the same three specimens by X-ray methods. These, averaging 95.6, were respectively 93, 98, and 96. These figures agree with those of Springer and Garrick (1964), except the caudal count of 93 , which is lower than the range given for $C$. leucas.

Weight.-Weights are available for only five specimens collected at San Carlos in 1964. They were as follows:

\begin{tabular}{lcccc}
\multicolumn{1}{c}{ Sex } & & Length $(\mathrm{mm})$ & \multicolumn{2}{l}{ Weight $(\mathrm{lb})$} \\
\cline { 1 - 1 } Female & 2,057 & & 182 & \\
Female & 1,800 & & 126 & \\
Female & 1,415 & & 61 (Not included in \\
Male & 1,852 & & 94 tables) \\
Male & 1,220 & 41 &
\end{tabular}

Sexual dimorphism.-Although we do not have sufficient data to make a proper analysis of sexual dimorphism, we have summarized the data for eight San Carlos sharks by sex, three males and five females (Table l).

As noted above, most of the differences between sexes are slight and probably more apparent than real, since the ranges in most cases overlap broadly. Nevertheless, there are a few measurements that should be noted.

(1) Gill openings appear to be a little longer in females than in males. We have already noted that the longest measurements for all five gill openings of all the 19 fresh. water sharks were from a single female, and all the shortest from a single male. The average figures for gill openings in San Carlos sharks by sex are also appreciably larger for females than for males, the divergence being greatest in the first, second, and third openings, and becoming progressively less in the fourth and fifth. Schwartz's figures agree in general with this observation.

(2) The distal margin (breadth) of the pelvic fin is somewhat greater in the female, as might perhaps be expected (although it does not necessarily follow), since a part of 
the male pelvic is modified as a clasper, not present in the female.

(3) The remaining five measurements which differ between the sexes, all involved with the length of the abdominal region of the body, are the distance from snout to pelvic insertion and cloaca, distance between bases of pectoral and pelvic fins, distance between pelvic and anal fins, and distance between insertions of pectoral and pelvic fins. These differ between males and females by an average of about $2.5 \%$ of the total body length each, the female having the longer measurement in all but distance between pelvic and anal. This latter measurement differs by $2.1 \%$ of body length, but it is smaller in the female than in the male. Thus it appears that externally, the pelvic fins and cloaca are displaced posteriorly by about $2.5 \%$ of the body length in females, while other features are placed approximately as in the males. It is not yet known if this is reflected internally in a longer body cavity in the females.

(4) Clasper lengths were determined in a total of five males, as follows:

\begin{tabular}{lcccc} 
Location & Year & $\begin{array}{c}\text { Body } \\
\text { Length, } \\
\text { mm }\end{array}$ & $\begin{array}{c}\text { Clasper Length, } \\
(\% \text { of Total } \\
\text { Length })\end{array}$ \\
\hline San Carlos & 1964 & & 1,852 & 9.2 \\
San Carlos & 1963 & 1,740 & 9.4 \\
E1 Castillo & 1963 & 1,584 & 3.1 \\
San Juan del Norte & 1963 & 1,475 & 2.1 \\
San Carlos & 1964 & 1,220 & 2.4
\end{tabular}

It is obvious that the claspers increase abruptly in length, and presumably the onset of sexual maturity occurs, when the total body length is between about 1,600 and $1,700 \mathrm{~mm}$. Clark and von Schmidt (1965) divided their series of immature and mature males at total body lengths of between 2,100 and 2,190 $\mathrm{mm}$, the group below these figures having claspers of $2.8-3.7 \%$ of total length, and those above, 5.7-10.4\%. It would appear that in Lake Nicaragua, the male sharks reach maturity at a smaller size than in Florida waters. This may be related to the observation of Springer (1960) that the average size of $C$. leucas from the vicinity of Trinidad is appreciably less than that of adults of the same species from the Gulf of Mexico.

Other than this slight difference in length of males at sexual maturity, the data of Clark and von Schmidt appear to bear out our observation on sexual differences, where measurements are available. They give no data on length of gill openings, but found about the same degree of difference in average breadth of pelvic fin between mature males and females as we did for San Carlos sharks. They did not find the same to be true of immature males and females, however. In regard to length of the abdominal region of the trunk, Clark and von Schmidt's distance between insertions of pectoral and pelvic fins (calculated from lengths of snout to pectoral and snout to pelvic) is $2.5 \%$ greater in mature females $(33.3 \%)$ than in mature males $(30.8 \%)$. The difference is also evident in the series of immature males and females (28.7 and $30.7 \%$ respectively). This feature is not exhibited by Schwartz's single large female as compared with three large males, nor in Boeseman's small female compared with two larger males.

\section{Origin of the Freshwater Shark POPULATION}

Theory of Pacific origin.-The explanation for the occurrence of sharks (C. leucas), sawfish (Pristis perotteti), and tarpon (Tarpon atlanticus), all primarily marine fish, in the fresh waters of Lake Nicaragua has a long and interesting history. Although now most evidence indicates an Atlantic origin for these fish, for many years the theory of Pacific origin was widely accepted. This idea gained currency from the theory of geologic origin of Lakes Nicaragua and Managua widely held during the latter part of the 19th Century and first half of the 20 th Century. The formation of the lakes, as then understood, was described by Hayes (1899), a geologist with the U. S. Nicaragua Canal Commission. He presented the hypothesis that, in early Tertiary time, there was open communication between the Atlantic and Pacific oceans across the isthmus below Nicaragua. By the latter part of the Tertiary, the coasts of Nicaragua were somewhat as they are now, except that a large bay extended from the present Gulf of Fonseca and northwest part of what is now Nicaragua southeastward to include all of the present Lake Managua and the northwest corner of the present Lake Nicaragua. Earlier volcanic activity in late Pleistocene or early Recent time gradually formed a barrier across the Bay of Nicaragua. Since precipitation behind the barrier exceeded evaporation, the level rose and probably overflowed the volcanic dam from time to time during periods of quiescence in the 
volcanic activity. As the height of the barrier was raised by successive eruptions, the impounded waters occupied not only the area of the former bay, but flooded the basins of the tributary streams and eventually the floor of the whole Nicaraguan Depression, and rose to a level probably $50 \mathrm{ft}$ or more above the present elevation of Lake Nicaragua which is about $128 \mathrm{ft}$ above sea level. Eventually it reached the lowest point of the Continental Divide, which at that time lay to the east, between the lake and the Caribbean, along the present Chontales Hills, and overflowed, probably near the present village of El Castillo. When this channel was first cut it consisted of deeply weathered rock and residual clay, which was rapidly cut down until the underlying rock was reached thus establishing the permanent level of the lake, which has been little changed to the present time.

Hayes has sometimes been credited with originating the idea that sharks, sawfish, and tarpon became established in the lake when they were trapped in the saltwater bay cut off from the Pacific. Although he had presented this theory, he did so by citing such a proposal made by Gill and Bransford (1877) as supporting evidence for his theory of the lakes' origin.

In the same paper in which they published the original description of the Lake Nicaragua shark, Gill and Bransford clearly set forth the Pacific theory of its origin, which has been so widely accepted. It is not clear what the sources were for their information on the geologic history of the basin in which the two large Nicaraguan lakes are found, but there is a hint of influence from Günther in their citation of his memoir of 1868: "E. Lake of Nicaragua.-Also the fishes of this lake are, with two exceptions, peculiar; like Lake Managua, it appears to have been part of a marine channel. . .." Günther did not mention the shark, sawfish, or tarpon specifically.

Gill and Bransford developed their idea as follows: "The element of especial interest in connection with the ichthyic fauna of the lake is the association of forms that we are in the habit of regarding as characteristically marine with those that are at least as exclusively fresh-water types. Thus, with the species of Cichlids and Characinids, of which no representatives have been found in marine waters, we have a species of Megalops, a shark, and a sawfish. ...
"The why and wherefore of such combinations of species are not entirely apparent. They may have resulted (1) from the intrusion of the salt-water types into the fresh waters, or (2) from the detention and survival of the salt-water fishes in inlets of the sea that have become isolated and gradually become fresh-water lakes. On the whole, it appears more probable that the latter is the case. By the uplift of the land, an inlet of the Pacific Ocean might have been shut off from communication from the ocean, and the character of the water would be soon changed by the copious showers of that tropical country. The shark, sawfish, Megalops, and other species mostly found in the sea, had, however, time to accommodate themselves to the altered conditions, and in this connection it must be remembered too, that most of the types in question are known to voluntarily ascend high up streams and even into fresh water."

This statement by Gill and Bransford, reenunciated by Hayes, for many years provided an easy and attractive explanation of the presence of the marine fauna of Lake Nicaragua. It was strengthened by the statement of Hayes (1899:344) that by personal communication, Gill had told him, "that the sharks of Lake Nicaragua are specifically identical with those found in adjacent portions of the Pacific Ocean, but distinct from those found in the Caribbean Sea." There is no further documentation, and we have not found any statement to that effect by Gill in the literature. In their cited paper (1877), published 22 years before Hayes' statement, Gill and Bransford clearly stated that the shark of Lake Nicaragua was "closely related to Eulamia Milberti and the kindred species." This is the sandbar shark of the Caribbean.

Theory of Atlantic origin.-In any case, some suspicion of the theory of Pacific origin was aroused with the realization that the affinities of the three large marine species were more pronouncedly with Atlantic relatives than those of the Pacific. The sawfish (largely $P$. perotteti, although according to Astorqui (1961) $P$. pectinatus is also present) appears to be identical with Atlantic sawfish, although there are closely allied forms on the Pacific Coast of Central America, whose exact relationship to Atlantic forms is yet to be established (Bigelow and Schroeder, 1953). The tarpon ( $T$. atlanti- 
cus) is identical with the tarpon of the Caribbean, and is not known to occur in the Pacific (Hildebrand, 1963). The Lake Nicaragua shark has long been known to be very closely related to $C$. leucas of the Atlantic and has been regarded as an almost identical derivative of that species.

As already noted, the lake form, known as C. nicaraguensis, was placed in synonymy with C. leucas by Bigelow and Schroeder in 1961. This would appear to have settled the question of Atlantic vs. Pacific origin of the shark conclusively. However, J. A. F. Garrick (pers. comm.) favors considering $C$. azureus, the closest relative of the lake shark in the Pacific, as also identical with $C$. leucas. So perhaps the question cannot be settled on purely morphological grounds. Nevertheless, since the sharks of the Atlantic and Pacific coasts of Central America have been isolated from one another at least since Pliocene time (Lloyd, 1963), it seems likely that some aspects of their biology might have diverged. At present we have studies under way comparing the parasites and electrophoretic serum protein patterns of the lake shark with those of marine $C$. leucas of the Atlantic and C. azureus (=C. leucas?) of the Pacific.

Although taxonomic and zoogeographic evidence weakens the theory of Gill and Bransford and of Hayes, the more recent evidence of geologists is perhaps even more damaging. Lloyd (1963), on the basis of structural evidence, proposed that the Nicaraguan Depression originally opened to the Caribbean Sea rather than to the Pacific Ocean, as a long inlet including the area now occupied by Lake Managua and Lake Nicaragua as well as a broad channel roughly along the present course of the Rio San Juan. Wilson and Auer (1942) and Zoppis and del Guidice (1958) believed that the Nicaraguan Depression is a graben that formed by subsidence during the late Tertiary and Quaternary and that surface drainage filled the depression, eventually overflowing eastward through what became the Rio San Juan. According to them the depression was never occupied by the sea. Swain (1961, pers. comm.) and Swain and Gilby (1964) also favored this proposal. They studied fossil ostracods in cores of the lake bottom sediment and found no evidence of true marine deposits to a depth of two meters in shallower parts of the lake. They state, however, that the evidence is incomplete until the deeper lake sediments have been thoroughly studied. Hartmann (1959) on the other hand, favored an earlier connection of the lake with the sea on the basis of occurrence in the lake of several living marine species of nematodes and ostracods. Hartmann does not agree with Swain and Gilby that these have migrated into the lake in recent times. Obviously, the lake's geological history is not yet fully understood.

The most compelling evidence on the question of Atlantic vs. Pacific origin is the simple fact that Lake Nicaragua is drained by a large, broad river, which flows into the Caribbean Sea, and that all three of the large, otherwise marine types of fish occurring in the lake are now thought to be identical with forms occurring in the Atlantic, and moreover are species which habitually congregate around the mouths of rivers, invade brackish water, and move up rivers (Bigelow and Schroeder, 1948, 1953; Carr, 1953; Schwart7, 1959; Darnell, 1962; Garrick and Schultz, 1963; Hildebrand, 1963).

\section{Arf thf Sharks of Lake Nicaragua LANDLOCKED?}

It is interesting to note that Oviedo (1535, 1855) who did not have the benefit of information on the geologic history of the area, referred to sharks along the coast that "often leave the sea and go up the rivers." He also stated that there were large sea animals, including sharks, that entered the lake from the sea; and that the sawfish, mentioned earlier, must have entered the lake by its outlet to the sea. Gill and Bransford (1877), however, referring to Oviedo, wrote, "The worthy chronicler must not be judged too harshly for his assumptions respecting the communicability between the sea and lake, because of the presence of sawfish and other marine types. In our days naturalists have based hypotheses and classifications upon even less data and in spite of known facts." Later they continued, "The numerous rapids of the river discharging from the lake discourage ... the idea that the [shark, sawfish and tarpon] have voluntarily ascended that river and entered the lake." Almost certainly because of this opinion and its citation by Hayes (1899), the shark and sawfish of Lake Nicaragua have, until relatively recently, been considered by most writers to be landlocked, regardless of where they came from originally. 
Increasingly, however, those who have had occasion to mention the matter have returned to the conclusion first suggested by Oviedo that the sharks and sawfish originally came up the river to the lake from the sea. Gill and Bransford (1877), although they regarded the sharks as landlocked, stated that "Sivers thinks that they come up the river." We have been unable, as yet, to determine the identity of Sivers. Apparently the first of recent questioners of the landlocked theory were Wilson and Auer (1942), geologists with the Servicio Geológico $\mathrm{Na}$ cional de Nicaragua. On the basis of their observations that the sharks looked like Caribbean sharks and that their numbers increased as they proceeded down the river, they wondered "whether they had been trapped at all, and whether they might not just as well have become accustomed to the brackish delta waters and in time have worked their way up the river in search of food." Marden (1944) also suggested that the river might be passable to the sharks and sawfish. Severin (1953) investigated this possibility quite thoroughly and, as proof, reported catching a shark at El Castillo "to which were attached two 8-inch remoras, practically dead, but still clinging stubbornly to their host." Unfortunately there were no photographs and the specimens were not preserved. Herre (1956) flatly stated that Lake Nicaragua was not landlocked and that during the rainy season he had no doubt that sharks could make the trip through the river in either direction. Springer (1963), discussing primary and accessory populations of sharks, suggested that the lake population represents an accessory population of $C$. leucas, recruited from marine migrants from the primary population. The idea that sharks pass through the river has also been proposed by Robert Dorion, G. S. Myers, and Cecil Miles (pers. comm.), Urist (1962), McCormick, et al. (1963), Astorqui (1964), Thorson (1964), as well as a number of local residents with whom we talked.

Seemingly, those who believed the sharks to be landlocked assumed that the Rio San Juan rapids provided the barrier to their movement. The Río San Juan is approximately 110 miles long, and in this distance drops about $128 \mathrm{ft}$. Although there is a strong current, it is not difficult to ascend such an elevation gradient. However, as noted, there are eight named rapids in the river (Fig. 1), several of them quite minor, but two or three relatively strong. Rápides de Machuca are almost invariably mentioned as the most severe, although Rápides del Castillo probably run a close second. All are hazards to navigation, especially in times of low water, even to native canoas if the boatmen are not familiar with the channel.

Carr (1953), who has undoubtedly done more than anyone to make the problem known, presented the theory of Pacific origin, but discounted it and suggested that the fishes came up the river before the rapids assumed their present form some 300 years ago. He proposed that, although evidently landlocked today, they came and went at will before the rapids built up. Carr stated that the bed of the river has changed since the 16th Century as a result of a series of earthquakes, causing a sharp reduction in its navigability. Almost from the time of its founding in 1524, Granada was a thriving port for seagoing traffic by way of Lake Nicaragua and Río San Juan, and received ships of as much as 120 tons. However, little more than a century later, according to Carr, shipping languished, because of the difficulty of negotiating the river, as well as the activities of Dutch and English pirates and privateers, and Granada's importance waned. It was these same changes in the riverbed which provided the barrier to movement of sharks and sawfish from the sea to the lake.

While it is a historical fact that seagoing vessels virtually ceased to ply the river and there may possibly have been some changes in the riverbed which reduced its navigability, whether produced by earthquakes and other geologic changes or by normal erosion of the channel, the changes would certainly not present as severe an obstacle to sharks as to sailing vessels. Smaller vessels have never stopped using the river as a freight route, and the ships that traveled the river in the 16 th and 17 th centuries did so even then only with great difficulty and danger. Early accounts of passage through the river describe conditions remarkably similar to those that exist today and appear to have existed with only minor changes throughout the history of Europeans in this hemisphere.

Carr tells of the early explorations down the Río San Juan from Lake Nicaragua in the 1520's, first by Capt. Rui Dias and then by Hernando de Soto, both of whom reached only the vicinity of the first rapids (el Toro); next by Martín Estete, who was stopped by abnormally low water over the 
rocks. It was not until 1539 that the full length of the river was traversed and the mouth discovered by an expedition under Alonso Caleras and Diego Machuca, the latter name was given to the most notorious of the rapids. Carr writes, "In 1578 three ships of war and a launch were built in [Lake Nicaragua] and used to descend the river and consolidate a route out to Cartagena, Havana, and Cadiz-the strange, unlikely route down through the rain forest of San Juan, where frigates would soon go bumping over the rocks and make a rich and busy Caribbean port of [Granada]."

These accounts are mentioned to point out that the rapids and shallows were present even before the river traffic began, but similar accounts keep recurring throughout the history of the region. Gage (1648), when the river traffic was still going on, wrote, "For although, whilst the [frigates] sail upon the lake they go securely and without trouble, yet when they fall from the lake to the river ... to go out to sea,... [t?]here is nothing but trouble, which sometimes makes that short voyage to last two months; for such is the fall of the waters in many places amongst the rocks that many times they are forced to unlade the frigates, and lade them again with help of mules which are there kept for that purpose by a few Indians that live about the river, and have care of the lodges made for to lay in the wares, whilst the frigates pass through those dangerous places to another lodge, whither the wares are brought by mules, and put again into the frigates." Although the ships passing upstream were likely empty and rode higher in the water, there is no doubt that they had to be pulled up certain portions of the river by men or mules. It is inconceivable that any sailing vessel could make its way against the powerful currents of the stronger rapids, under sail alone or by poling alone.

According to Carr, the series of earthquakes believed to have raised the bed of the river occurred from 1630 to 1663 and by the end of that period seagoing traffic was virtually at an end. Yet, shortly after this time, to finance the fortification of the river, a tax of 50 pieces of eight was levied for each frigate that left for spain. Ol)viously, there were still ocean-going vessels on the river in spite of the carthquakes. Carr states that they were almost surcly trundled empty through the rapirts and aheir cargoes portaged, but this was not different from what had been done when Gage described the trip downriver.

That the river was still navigable, albeit possibly for smaller vessels, is shown beyond doubt by the passage of an English fleet of 50 ships and 2,000 men as far as El Castillo in 1762, and another British expedition in 1779 . John L. Stephens (1841), U. S. Minister to the Confederation of Central American States, who made one of the early American surveys for a canal route across Nicaragua, described the rapids as to location and depth and stated, "There are no cataracts or falls; all the obstructions are from rapids, and it is at all times navigable both up and down for piraguas drawing from three to four feet of water." Furthermore, in 1849, Commodore Vanderbilt established an interocean transit line across Nicaragua to transport prospectors to the California gold fields. From San Juan del Norte (Greytown), a 120-ton vessel (probably as great a tonnage as any that traveled the river in the 16th and 17 th centuries) ascended the river regularly to EI Castillo, where the passengers transferred to another ship which completed the trip up the river and across the lake to a stage line that ran the last few miles to the Pacific Coast. Squier (1852), in another canal survey, described the rapids in some detail, and mentioned the steamer, Orus, of the American Atlantic and Pacific Ship Canal Company, which lay wrecked on the rocks of Rápides de Machuca. At El Castillo he referred to "the quarters of a small garrison kept here ... to assist boats in passing the rapids of the Castle, which, although narrow, are very powerful, and better deserving the name of falls than rapids. Here the boats have to be "tracked up" by sheer force; and it is usual for all passengers to land, and to lighten the boat in every way possible. It is often necessary to take out a considerable part of the freight, or to wait for the arrival of another boat, so as to join forces in making the ascent."

Sultan (1932), Marden (1944), and McCormick, et al. (1963) refer to the lake steamer VICTORIA which sailed from Baltimore to Greytown in 1882 and made its way up the Rio San Juan into the lake.

To obserse the condition of the rapids and to study the narigability of the Rio San Juan, we traveled from its soure to its mouth in a dugout with oubmard motor in June J963 In June lekis. we repeated the 
trip and also made the return trip up the river. In 1963, an unusually dry period had been broken by the rains usual for that time of year, and the river had risen somewhat, but was not at its deepest. In 1965, the level was lower than in 1963. Our boat with our equipment descended all the rapids both years with no more difficulty than an occasional broken propellor pin, and the upstream trip was made with only minor problems. We observed several barges loaded with produce and freight making their way up the river, both above and below the rapids as well as between rapids. They were from 30 to $50 \mathrm{ft}$ long, drew from 1 to $3 \mathrm{ft}$ of water, and were driven by gasolineor diesel-powered tugs. Several were photographed, the one at El Castillo in various stages of ascending the rapids. We were told that barges regularly make their way up and down the river, except at times of especially low water. Channels exist at some point in each of the rapids where such vessels can pass with little danger if the pilot knows the river.

If, as observed, vessels of the size of barges can make their way up the river, it seems completely indefensible to assume that the rapids present a barrier to the movements of such strong swimmers as sharks, or for that matter to the more sluggish sawfish. Even more to the point, in 1965 we saw sharks in the vicinity of Rápides del Toro, including at least three actually in the rapids, headed upstream. At El Castillo we saw sharks immediately above and below the rapids, and two actually in the uppermost part of the main rapids. We also saw several in the lower part of Rápides de Machuca. Some of the sharks seen were threshing about in shallow water, but others were swimming freely, and they were usually heading upstream.

We observed, by actual collection of sharks, that they were plentiful at both the source and the mouth of the river, as well as at El Castillo. By questioning numerous local residents we were convinced that the sharks occur throughout the length of the river, as was stated by Gill and Bransford (1877) as well as many others.

It appears to us that (1) since the sharks occur the full length of the river, (2) are of the same species throughout the river and in the Caribbean Sea, and (3) since the rapids almost certainly do not form a barrier to the movement of sharks, there is no real basis for the belief that the shark population in the lake is landlocked. Furthermore, in view of the statements and descriptions of the river from earlier times, there is no reason to believe that there has been any change in the river bed extensive enough to affect the status of the shark in the lake. We believe it unlikely that the sharks (or the sawfish, tarpon, or any marine species that may inhabit the lake), have been barred from passage from the sea to the lake at any time since Europeans arrived in the New World, and probably not since the river assumed its present course and approximate elevation gradient.

Although circumstantial evidence is now strong in support of the free communication between the Caribbean Sea and Lake Nicaragua, there is as yet no definitive proof that the sharks actually pass between them. The answer to this question must come from a tagging program which is about to be instituted.

\section{ACKNOWLEDGMENTS}

The study was supported by N.S.F. Grant No. G-23574, U.S.P.H.S. Grant No. HE09075, and by the University Research Council of the University of Nebraska.

For courtesies and services too many to enumerate, we extend grateful recognition to the following: Dr. L. G. Clark, Director, and other members of the staff of the University of Pennsylvania School of Veterinary Medicine, Leptospirosis Field Laboratory at Managua; Padre Ignacio Astorqui, as well as the Rector, Padre José Maria Gondra, and other members of the staff and student body of Colegio Centro America at Granada; Sr. Armando Vega of Granada; Sra. Concepción Marenco de Sánchez of Finca la Punta, Granada; at San Carlos, Dr. Rodolfo Correa Coronel, Lt. Ernesto Fong of La Guardia Nacional, Sr. Luis F. Estrada, Sr. and Sra. Antonio McRea, and Sr. Ramón Cunningham; Sr. and Sra. José Mena and family of San Juan del Norte; and Sr. Lester Hodgson of Managua who accompanied us throughout our trip in 1963. For numerous discussions, extensive correspondence, and the loan of books and equipment, we thank Mr. Robert C. Dorion of Guatemala City. We have consulted on various aspects of our study and appreciate a variety of help received from Eugenie Clark, J. A. F. Garrick, Thomas R. Howell, Cecil Miles, George S. Myers, Stewart Springer, Victor G. Springer, and 
Frederick M. Swain. However, we accept full responsibility for all conclusions and statements made in our paper.

This paper constitutes part of the studies from the Department of Zoology and Physiology, University of Nebraska, No. 375.

\section{Literature Cited}

AnEs, C. H. 1893. Sharks in fresh water. Science 22:111.

Anonymous (H. U.). 1943. fresh-water sharks of Nicaragua. Sci. Monthly 57:186-188.

Astorqui, I. 1961. Fishes from the great lakes basin of Nicaragua. M.S. thesis, Univ. Miami, Coral Gables, Fla.

1964. El tiburón del Lago Cocibolca. La Prensa, 14 June 1964, Managua, Nicaragua.

BeLt, T. 1874. The naturalist in Nicaragua. J. M. Dent \& Sons, London, England.

Bigelow, H. B. AND W. C. SChroeder. 1948. Sharks. In: Fishes of the western North Atlantic. Mem. Sears Found. Mar. Res., Yale Univ., New Haven, Conn. 1(1):59-576.

AND - 1953. Sawfishes, guitarfishes, skates and rays, In: Fishes of the western North Atlantic. Mem. Sears Found. Mar. Res., Yale Univ., New Haven, Conn. 1 (2) :1514.

. 1961. Carcharhinus nicaraguensis, a synonym of the bull shark, $C$. leucas. Copcia 1961(3):359.

BoEsEman, M. 1956. Fresh-water sawfishes and sharks in Netherlands New Guinea. Science 123:222-223.

- 1964. Notes on the fishes of western New Guinea III. The fresh water shark of Jamoer Lake. Zool. Meded. 40:9-22.

CARR, A. 1953. High jungles and low. Univ. Florida Press, Gainesville, Fla.

Clark, E. ANd K. von Schmidt. 1965. Sharks of the central Gulf Coast of Florida. Bull. Mar. Sci. 15:13-83.

DARnell, R. M. 1962. Fishes of the Rio Tamesí and related coastal lagoons in castcentral Mexico. Pub. Inst. Mar. Sci. Univ. Texas 8:299-365.

Eigenmann, C. H. 1893. Catalogue of the fresh-water fishes of Central America and southern Mexico. Proc. U. S. Nat. Mus. 16: 53-60.

- 1909. Catalogue of the fresh-water fishes of tropical and south tempcrate America. Rept. Princeton Univ. Exped. to Patagonia, 1896-1899, Vol. III, 2, Part IV.

GaGE, T. 1648. A new survey of the West Indies. R. Cotes, London, England. Reprinted by Robert M. McBride \& Co., New York, N. Y. 1929.

Garrick, J. A. F. ANd L. P. Schultz. 1963. A guide to the kinds of potentially dangerous sharks. In: P. W. Gilbert, ed.; Sharks and survival. D. C. Heath \& Co., Boston, Mass. Pp. 3-60.

GiLbFRT, P. W., ed., 1963. Sharks and survival. D. C. Heath, \& Co., Boston, Mass.

GiLl, T. 1884. Salt-water fish-types in freshwater. Nature 29:573.
22:165.

1893. Sharks in fresh water. Science the fishes of Lake Nicaragua. Proc. Acad. Nat. Sci. Phila. 1877:175-191.

Günther, A. 1868. An account of the fishes of the states of Central America, based on collections by Capt. J. M. Dow, F. Godman, Esq., and O. Salvin, Esq. Trans. Zool. Soc. London 6:377-494.

Hardman, E. F. 1884. Sea fish in freshwater rivers. Nature 29:452-453.

Hartmann, G. 1959. Beitrag zur Kenntnis des Nicaragua-Sees unter besonderer Berücksichtigung seiner Ostracoden (mit Beschreibung von 5 neuen Arten). Zool. Anz. 162:269-294.

Hayes, C. W. 1899. Physiography and geology of region adjacent to the Nicaragua canal route. Bull. Geol. Soc. Amer. 10:285-348.

Herre, A. W. C. T. 1956. Marine fishes in fresh water. Science 123:1035-1036.

Hildebrand, S. F. 1963. Family Elopidae. In: Fishes of the western North Atlantic. Mem. Sears Found. Mar. Res., Yale Univ., New Haven, Conn. 1(3):111-131.

JORDAN, D. S. 1887. A preliminary list of the fishes of the West Indies. Proc. U. S. Nat. Mus. 9:554-608.

AND B. W. Eyermann. 1896a. The fishes of North and Middle America. Bull. U. S. Nat. Mus. 47:1-1240.

AND — 1896b. A check-list of the fishes and fish-like vertebrates of North and Middle America. Rep. U. S. Comm. Fish. (1895) , pp. 207-584.

list of the fishes and fishlike vertebrates of North and Middle America north of the northern boundary of Venezuela and Colombia. Rept. U. S. Comm. Fish., 1928, App. 10, 670 pp.

Lloyd, J. J. 1963. Tectonic history of the south Central-American origin. Amer. Assoc. Petrol. Geol., Mem. 2:88-100.

LütKen, C. 1879 . Smaa bedrag til selachiernes naturhistorie. Vidensk. Meddel. 31:45-68.

MARDEN, L. 1944. A land of lakes and volcanoes. Nat. Geogr. 86:161-192.

McCormick, H. W., T. Allen, and W. E. Young. 1963. Shadows in the sea. Chilton, Inc., New York, N. Y.

МеEк, S. E. 1907. Synopsis of the fishes of the great lakes of Nicaragua. Field Mus. Publ. Zool. 7:97-132.

Ogtri, M. 1964. Rectal glands of marine and fresh-water sharks: comparative histology. Science 144:1151-1152.

Oviedo, Y Valdés, G. F. 1526. De la natural hystoria de las Indias. Toledo, Spain. En glish translation: Natural history of the West Indies. S. A. Stoudemire, ed., Univ. of $\mathrm{N}$. Carolina studies in the romance languages No. 32. Univ. N. Carolina Press, Chapel Hill, North Carolina, 1959.

- 1535. Historia general y natural de las Indias, islas y tierra-firme del mar océano. Primera parte. Sevilla, Spain. (Segunda parte, 1557. Valladolid, Spain.)

Ind. 1855. Historia general y natural de las 
Tercera parte. First published by La Real Academia de la Historia. José Rodriguez, Madrid, Spain.

Regan, C. T. 1908. Pisces. In: Biologia Centralia-Americana 8:1-203.

ScHwartz, F. J. 1959. Two eight-foot cub sharks, Carcharhinus leucas (Müller and Henle), captured in Chesapeake Bay, Maryland. Copeia 1959(3):251-252.

1960. Additional comments on adult bull sharks Carcharhinus leucas (Müller and Henle), from Chesapeake Bay, Maryland. Chesapeake Sci. 1(1):68-71.

Severin, K. 1953. The landlocked man-eaters. True (Magazine) July 1937, pp. 37-39, 95-96. Sмiтн, H. M. 1893. Sharks in Lake Nicaragua. Science 22:166-167.

SPRINGER, S. 1960 . Natural history of the sandbar shark Eulamia milberti. U. S. Fish and Wildl. Serv., Fish. Bull. 178, 61:1-38.

W. 1963. Field observations on large sharks of the Florida-Caribbean region. In: P. W. Gilbert, ed., Sharks and survival. D. C. Heath \& Co., Boston, Mass. Pp. 95-113.

Springer, V. G. AND J. A. F. Garrick. 1964. A survey of vertebral numbers in sharks. Proc. U. S. Nat. Mus. 116:73-96.

SQUIER, E. G. 1852. Nicaragua; its people, scenery, monuments, and the proposed interoceanic canal. Vols. 1 and 2. D. Appleton \&. Co., New York, N. Y.

STEPHENS, J. L. 1841. Incidents of travel in Central America, Chiapas, \& Yucatan. (1949 Ed., Rutgers Univ. Press. New Brunswick, N. I).
Sultan, D. I. 1932. An army engincer explores Nicaragua. Nat. Geogr. 61:592-627.

SwaIn, F. M. 1961. Reporte preliminar de los sedimentos del fondo de los Lagos Nicaragua y Managua, Nicaragua. Bol. Serv. Geol. Nac., Nicaragua 5:11-29.

- AND J. M. Gilby. 1966. Ecology and taxonomy of Ostracoda and an alga from Lake Nicaragua. Pub. Staz Zool. Napoli, Suppl. 34.

Thorson, T. B. 1962a. Body water partitioning of the fresh water shark, Carcharhinus nicaraguensis, compared with that of marine selachians. Amer. Zool. 2 (3) :452-453 [abstr.]. $1962 \mathrm{~b}$. Partitioning of body fluids in the Lake Nicaragua shark and three marine sharks. Science 138:688-690.

1964. Are the freshwater sharks of Lake Nicaragua landlocked? Amer. Zool. 4(3) : 275 [abstr.].

URIST, M. R. 1962. Calcium and other ions in blood and skeleton of Nicaraguan fresh-water shark. Science 137:984-986.

Wilson, T. C. AND W. F. Auer. 1942. Unpublished summary report, Geology of Pacific Coast area, Nicaragua. Serv. Geol. Nac., Nicaragua, $30 \mathrm{pp}$.

ZopPIS, L. AND D. DEL Guidice. 1958. Geologia de la costa del Pacifico de Nicaragua. Bol. Serv. Geol. Nac., Nicaragua 2:33-68.

Department of Zoology and Physiology, University of Nebraska, Lincoln, NeBRASKA 68508. 